Commentary

\title{
Addressing Environmental Health Problems in Ogoniland through Implementation of United Nations Environmental Program Recommendations: Environmental Management Strategies
}

\author{
Okhumode H. Yakubu \\ Department of Public Health Sciences, College of Health and Social Services Building, New Mexico State \\ University, 1335 International Mall, Suite 326, P.O. Box 30001 MSC 3HLS, Las Cruces, NM 88003-8001, USA; \\ ohyakubu@nmsu.edu; Tel.: +1-575-650-4126
}

\begin{abstract}
In August 4 2011, United Nations Environmental Program (UNEP) submitted an unprecedented, scientific, groundbreaking Environmental Assessment Report (EAR) of Ogoniland, to the Nigerian government. This was the outcome of a 14-month intensive evaluation of the extent of pollution. It was intended that UNEP's recommendations would be implemented to restore the devastated environment, on the one hand, and on the other, counteract the numerous environmental health issues that have for decades, plagued Ogoniland. However, five years post EAR, and, despite the seriousness of the situation, no significant resolution has occurred, both on the part of the government, and on the part of Shell Petroleum Development Company (SPDC) or Shell. To date, millions of Niger Delta residents, particularly those living in the oil-bearing communities, continue to suffer severe consequences. Although, the assessment was conducted in Ogoniland, other communities in the Niger Delta are also affected. This article explores prevailing issues, using Ogoniland (a microcosm of the Niger Delta) as an example. A multidisciplinary approach for sustainable mitigation of environmental health risks in the Niger Delta is paramount, and Environmental Management tools offer valuable strategies. Adopting UNEP's recommendations for addressing environmental health problems requires implementing the Environmental Management/Environmental Management System (EM/EMS) model.
\end{abstract}

Keywords: Environmental Assessment Report (EAR); environmental health; Environmental Management/Environmental Management Systems (EM/EMS) Model; Environmental Management Plan (EMP); Multinational oil companies (MOCs); Niger Delta; Ogoni; Ogoniland; Shell Petroleum Development Company (SPDC); United Nations Environmental Program (UNEP)

\section{Introduction}

Decades of oil exploitation, exploration, and production activities in the Niger Delta have led to severe environmental degradation that has created complex problems in the region. Environmental exploitation has been a major point of contention between the Nigerian Government, multinational oil companies (MOCs), SPDC in particular, and the communities affected by oil pollution. Many years of struggle between Ogoni communities and Shell to clean up oil spills from their operations have brought no change. Shell has paid little attention to the cry of these people whose ecosystems, ecology and consequently, means of livelihood, have been severely impacted [1]. The relentless efforts channeled towards environmental justice by the impoverished Ogoni people culminated in the birth of the Movement for the Survival of the Ogoni People (MOSOP). MOSOP-led protests prompted the Nigeria federal government, to invite UNEP to conduct an environmental assessment (EA), and propose lasting solutions to the environmental problems created by Shell, thereby ending the prolonged feud between both parties [1, 2]. Ogoni is represented by MOSOP at the Unrepresented Nations and Peoples Organization (UNPO). UNPO assisted MOSOP to gain immense international exposure, by way of the media, and through meetings with United Nations. Although the Ogoni 
people lost some of their prominent leaders, including MOSOP's founder and leader, Ken SaroWiwa, nonetheless, they against all odds, ousted SPDC from operating in their communities in 1993, making their situation even more popular within the international community [3].

\section{Overview of Oil Exploration in the Nigerian State}

In August 3, 1956, oil was discovered in commercial quantities in Oloibiri, Ogbia local government area (LGA), in Bayelsa State, of the Niger Delta [4]. This discovery placed Nigeria among the group of oil-producing nations which today remains Africa's largest producer. It is estimated that Nigeria has a daily production of 2.4 million barrels, making it the 13th largest producer of oil worldwide [5]. Also, Nigeria has the second largest proven oil supplies in Africa and the 10th largest in the world. Interestingly, amidst the complexity of ethnic, environmental, political, and social, problems besetting this highly valuable resource, it remains the principal export, and largest source of foreign earnings [5]. Petroleum has accounted for $80 \%$ of Nigerian federal government's revenue, and $95 \%$ of the country's export earnings. Apparently, oil discovery signified the dawn of Nigerian's transformation both in economic and political terms [6]. Besides being the source of all the nation's petroleum resources, the Delta buoys African's most extensive wetland- one of the largest in the world. Situated in the South geopolitical region of the country [6], the Niger Delta is considered one of the most densely populated African regions [7], also serving as habitat to certain very rare species [8]. It has the largest mangrove forests in Africa, and is the third largest in the world. It represents the most abundant part of the country in terms of petroleum resources, and diverse natural ecosystems, supportive of numerous species of terrestrial and water-living organisms [9-11].

\subsection{Ogoniland}

Ogoniland has a population of close to 832,000 [2], and population density of $1250 \mathrm{~km}^{2}$ [6]. The region administratively has four sub divisional local government areas, namely: Eleme, Gokana, Khana, and Tai [2]. Covering around 100,000 $\mathrm{km}^{2}$ in Rivers State, Ogoniland is one of the prominent areas in the Niger Delta region, and has been the site of oil industry operations since the late 1950s. It has a calamitous history of pollution from oil spills, gas flares, and oil well fires.

The area is naturally endowed with an abundance of rivers, creeks, and streams. Consequently, it has predominantly traditional fishers, and farmers. In the past, it has been referred to as the "Food basket of the Niger Delta" because it produced cash crops for neighboring Niger Delta regions as well as subsistence agriculture. This traditional practice enhanced sustainable management of the abundant natural resources.

\subsection{Oil Conflict}

Undoubtedly, the history of oil operations in the Niger Delta is one characterized by continued dispute among the people and the oil industry, on the one hand, and strong discord between the people and the government, on the other. This led to a morbid atmosphere of animosity, buckpassing, and distrust over the years [2]. The situation was further fueled, by a military dictatorship kind of government, ruling at the time.

The ensuing years of Shell's eviction from Ogoniland in 1993, was marked with various unfruitful negotiations and protests-no proffered solution seemed to work, either to favor or meet the prospects, and demands of any of the parties involved. 


\subsection{The UNEP EA}

At the dawn of a new democratic government in 1999, spearheaded by retired General Olusegun Obasanjo, efforts directed towards moving forward and ending the deadlock, commenced in 2005. Therefore, the government in consultation with various stakeholders invited UNEP, to conduct an EA, with a view to reaching an agreement that would benefit all parties. This supposedly, would ultimately foster the resumption of business operations by Shell in Ogoniland. UNEP's EA entailed a 14-month exhaustive evaluation of diverse parameters, including aquatic lives, air pollution, contaminated land, ground water, surface water, sediments, soil, public health, industry practices, and institutional problems [1,2]. The outcome of this was a cutting-edge report that has been described as "...epitomizing the best available insight of the Ogoni situation, as well as the implication for impacted people..." [2]. Also considered one of the most intricate on-the ground evaluations ever carried out by UNEP, the EAR provides first time, systematic and scientific based evidence, available to the public on the exact nature, magnitude, and impacts of oil pollution in Ogoniland. Furthermore, the report contains recommendations that would bring about restoration of the devastated ecology and ecosystems, including urgent measures requiring immediate action, such as providing safe drinking water to communities with contaminated water.

\section{Oil Production-Related Environmental Health Problems}

\subsection{Air Quality}

The environmental pollutants discharged from the continued flaring of gas in Ogoni and other communities of the Niger Delta, severely impact air quality that has detrimental consequences on the people. Even though legislation regulating gas flaring has been passed with the aim of completely phasing it out, including the 1984 complete prohibition [12] target, the operation continues undiminished. Despite claims of a dearth of studies aimed at evaluating the health impact of poor ambient air quality on humans in the Niger Delta [13], there is still reasonable amount of published articles disclosing substantial (adequately sufficient to motivate necessary action) information related to the fact.

A major observable lifestyle of the Ogoni people is the fact that most of their daily activities such as farming, fishing, bathing, cooking, and most other domestic chores are outdoor-related. Hence, they are being exposed to the "too numerous to count (TNTC)" toxic chemicals, including benzene, dioxin, and benz[a]pyrne [14, 15].

The quantities of these emissions far exceed both local and International standards, and have had various severe health consequences [16] such as asthma, respiratory difficulties, premature deaths, cancer, and miscarriages among pregnant women $[12,16,17]$. Some of the health impacts are shown in Table 1. 
4 of 18

\begin{tabular}{|c|c|c|}
\hline S. No. & Chemical name & Human health effect \\
\hline 1. & $\begin{array}{l}\text { Alkanes: methane, ethane, } \\
\text { propane }\end{array}$ & $\begin{array}{l}\text { Low levels: Can result in swelling, itching and inflammation [18]. } \\
\text { High levels: May cause skin infections such as eczema and acute lung swelling [18]. }\end{array}$ \\
\hline 2. & Alkenes: ethylene, propylene & May result in weakness, nausea and vomiting [19]. \\
\hline 3. & $\begin{array}{l}\text { Benzene, toluene, ethyl, } \\
\text { Xylene (BTEX) }\end{array}$ & $\begin{array}{l}\text { They are toxic and are either carcinogenic or probable carcinogens }[18,20] \text {. Targets } \\
\text { on exposure are usually the nervous system and blood forming organs [20]. }\end{array}$ \\
\hline 4. & Carbon monoxide & $\begin{array}{l}\text { Low levels: Can cause permanent damage to the heart and brain [18]. } \\
\qquad \text { May harm the mental development of fetus and children [18]. } \\
\text { High levels: Can lead to miscarriage and death [18]. }\end{array}$ \\
\hline 5. & Hydrogen sulphide & $\begin{array}{l}\text { Low levels: Nausea, headaches, delirium, disturbed equilibrium, tremors, } \\
\text { convulsions, and skin and eye irritation [18]. } \\
\text { High levels: Respiratory tract and mucous membrane irritation; may cause } \\
\text { immediate or delayed pulmonary edema [18]. May result in } \\
\text { extremely rapid unconsciousness and death [18]. }\end{array}$ \\
\hline 6. & Nitrogen dioxides $\left(\mathrm{NO}, \mathrm{NO}_{2}\right)$ & $\begin{array}{l}\text { Low levels: Cause irritation of eyes, nose, throat, and lungs. Cough, shortness of } \\
\text { breath, tiredness, and nausea may also occur. Build-up of fluid in the } \\
\text { lungs } 1 \text { or } 2 \text { day(s) after exposure is also possible [19]. } \\
\text { High levels: May result in rapid burning, spasms, and swelling of the upper } \\
\text { respiratory tract and throat tissues. Reduced oxygenation of body } \\
\text { tissues, a build-up of fluid in lungs. Death [19]. }\end{array}$ \\
\hline 7. & Sulphur dioxide & $\begin{array}{l}\text { Low levels: Asthmatics are very sensitive to respiratory effects [18]. } \\
\text { High levels: Burning sensation of the nose and throat, breathing difficulties, and } \\
\text { severe airway obstructions were observed in miners exposed to a } \\
\text { copper mine explosion [18]. A } 100 \mathrm{ppm} \text { in } 100 \text { parts of air has been } \\
\text { demonstrated to be immediately dangerous to human health and life } \\
\text { [18] }\end{array}$ \\
\hline
\end{tabular}

\section{Table 1. Some human health effects of gas flare pollutants in Ogoniland}

\subsection{Food Quality/Supply}

Due to the widespread pollution, agricultural lands have been severely impacted causing a reduction in the quantity of harvest. In addition, because of the direct contact with the plants, or indirect contact via the absorption of nutrients from contaminated soils, the quality of food is severely impacted [21]. Notable among these were the high reduction in the ascorbic acid content of vital vegetables like water leaf (Talinum triangulare), spinach (Spinach oleraceae) and garden egg (Solanum melongena), whose vitamin C contents were reduced by $36 \%, 40 \%$ and $19 \%$ respectively [22]. Also, the major staple, cassava (Esculenta spp.) planted in oil polluted soils had its crude protein content reduced by $41 \%$ [23].

Although, according to UNEP's 2011 findings, fish contamination was not as high as expected, they discovered that the fish had migrated to safer and cleaner water. This is forcing farmers to travel very long distances from their localities. In terms of health impacts on the locals, [24] argue that the prevalence of diarrhea in the Niger Delta is on the rise, as a result of the consumption of fish and other animals contaminated by hydrocarbons contained in the spilled oil. Furthermore, it has been determined that bioaccumulation of benzo (o) pyrene, other hydrocarbons, and heavy 
metals, have occurred in toxic amounts in major high protein content sea foods sources, such as periwinkle (Tympanotonus fuscatus) and the Mudskipper (Periophtalus papillio), [25].

Additionally, accumulation of oil in plants' roots causes them to wilt [2].

\subsection{Waste Disposal/ Hazardous Chemicals}

Produced water is the major waste product generated from petroleum exploration, and production activities. Others include, spent drilling muds, and drilling cuttings. Produced water is known to be a complex composition of numerous hazardous chemicals, including large quantities of heavy metals, inorganic, and organic substances, including naturally occurring radioactive materials (NORMs). [26, 27]. According to [28], the two main disposal methods for produced water, are environmental unfriendly. The array of hazardous chemicals contained in petroleum waste streams and their unwholesome disposal, has resulted in untold damage to environmental media that are very unyielding to known remediation technologies.

In its 2011 Assessment of Ogoniland, one of the major findings by UNEP project team was the indiscriminate disposal of numerous industrial packing bags containing 1,000-1,500 $\mathrm{m}^{3}$ of waste, suspected to be cuttings from oil drilling operations. These were dumped at an open site. Such open waste disposal in unlined pits, is an indication of how compliance with environmental regulations is severely contravened, by all the parties involved, including generator, transporter, as well as disposal agents [2].

\subsection{Water Quality}

Oil spills end up in the environment including water, contaminating waterways, and does significant detriment to marine life, and sources of water for domestic use. Further, discharged oil often sinks into ground water contaminating it. It has been established that such polluted ground water is usually difficult to remediate, and the process of remediation can take many years. Once underground, the polluted water system is transported within and between water systems that end up in wells and streams that supply the surrounding communities. These communities depend on them for their only source of drinking water [29].

Studies indicate that acid rain is widely distributed in the Niger Delta region [30-33]. On the average a $\mathrm{pH}$ value of 5.06 from a range of $4.98-5.15$ [32] is usually obtained. This has had a tremendous impact on the roofs of houses, as homes with corroded roofs are commonplace within the communities.

The U.S. Department of Energy (DOE), estimates that well above 4000 oil spills, resulting in the emission of millions of barrels of crude oil into various surface water sources, including creeks, streams and rivers occurred in the Niger Delta as far back as 1960 [34]. To date, water pollution remains one of the major environmental public health problems arising from extensive oil operations in the region. The health of a considerable number of Ogoni communities has been severely impaired due to surface and underground water contamination [2]. 


\subsection{Other Problems}

\subsubsection{Policy Issues}

Records indicate the existence of well over 25 major environmental laws in the country. Prominent among them are, according to [35] the Oil Pipelines Act (OPA) 1956 (amended in 1965); Oil in Navigable Waters Acts (ONWA, 1968); Petroleum Acts (1969); Associated Gas Re-injection Act (AGRA, 1979); the Federal Environmental Protection Agency (FEPA) Act (1988); the National Policy on the Environment, 1989 (revised in 1999); National Environmental Protection (Effluent Limitations) Regulations (1991); Environmental Protection (Pollution Abatement in Industries Generating Wastes) Regulations (1991); Environmental Impact Assessment (EIA) Act (1992), and Department of Petroleum Resources (DPR) Environmental Guidelines and Standard for the Petroleum Industry in Nigeria (EGASPIN) (2002). Unfortunately, none of these laws are fully implemented or enforced by Nigerian courts. Furthermore, there is ample evidence that since the late 1930s when businesses commenced oil prospecting in the nation, there has hardly been any account of penalties imposed on sanctionable environmental crimes arising from oil exploration and production activities [36]. It is well known that in many instances the oil companies either adopt substandard clean-up methods or turn a blind eye to oil spills, such as the 2008 spills in Ogoni communities of Bodo and Goi, linked with the operations of SPDC [37]. He further asserts that hosts of the environmental issues that have befallen the region have their roots in the Land Use Decree of 1978, which deprived communities the ownership rights or claims, and rendered them powerless in oil decision- making. This resulted in the oil companies having full access to communal lands with no restrictions, thereby causing devastation, and consequently, increasing poverty in the region.

\subsubsection{Socioeconomic Issues}

The majority of people do not have adequate access to clean water or healthcare. According to United Nations Development Program [38], more than 60 per cent of the people in the region depend on the natural environment for their livelihood. For many, the environmental resource base, which they use for agricultural activities, fishing, and the gathering of forest products, is their principal or sole source of food. Oil spills on land seriously affects the growth and development of crops, and damage the soil quality, fertility, and ultimately, its productivity, rendering farmers in the communities unproductive. In addition, oil in water destroys fisheries, and pollutes water that people use for drinking and other domestic purposes. When gas is flared, the combustion is often incomplete, so oil droplets fall on waterways, crops, houses and people. Some homes in the communities have been rendered inhabitable, due to the prevailing unsanitary environmental conditions. People, especially young men, who have been deprived of their means of livelihoods have resorted to pipeline vandalization, to "make up" for their losses, and to combat the lingering impoverishment that has befallen them [39]. This in a way "sustains" the vicious circle-the convoluted problem (Figure 1). 


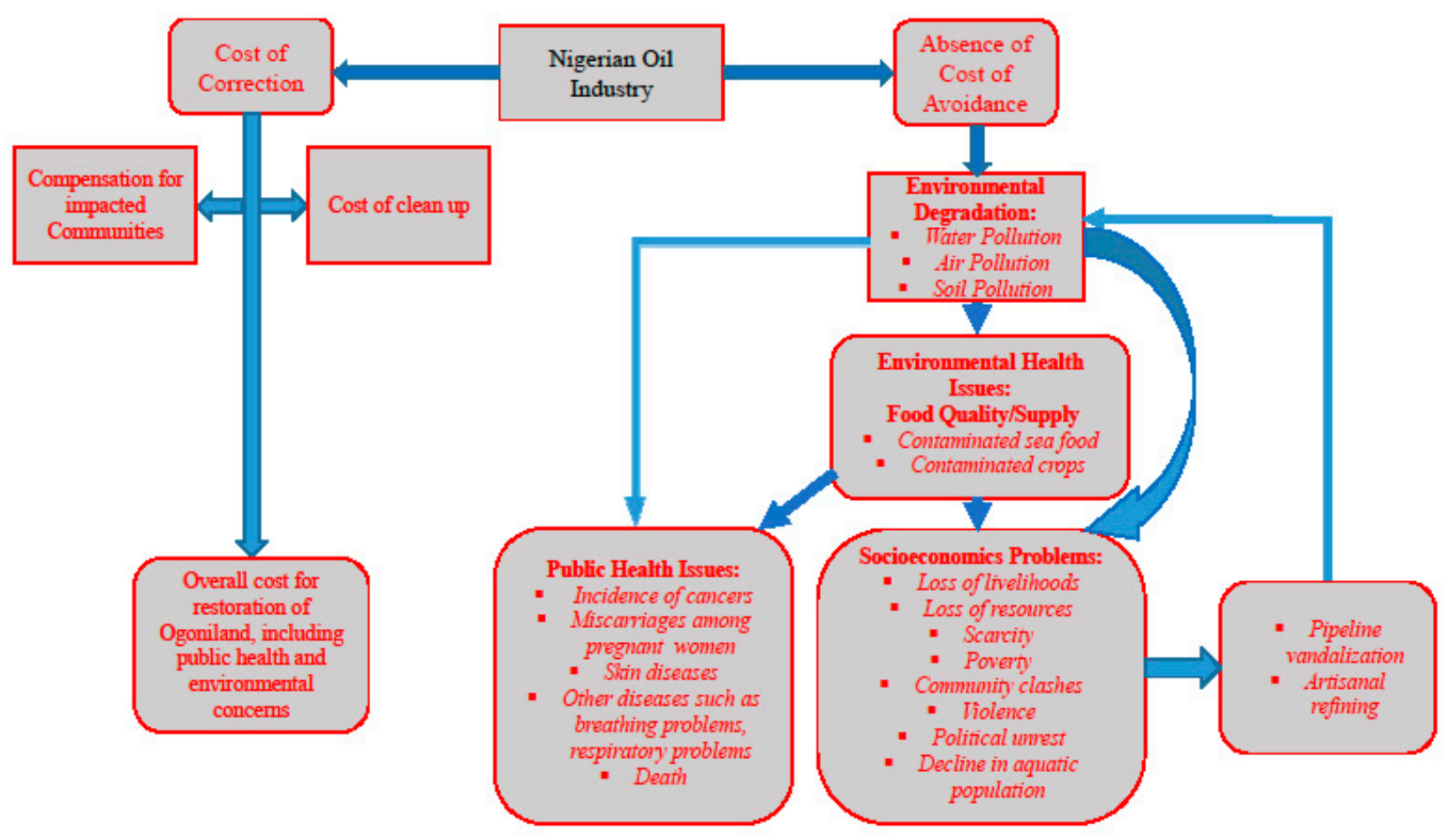

Figure 1. "Cost of Quality" conceptual framework showing the convoluted environmental, public health, and socioeconomic issues in Ogoniland.

\subsection{UNEP EAR}

UNEP's experts in a 14-month period, assessed over 200 sites within the Ogoni confines, evaluated approximately $122 \mathrm{~km}$ of pipeline rights of way; reviewed an estimated 5,000 medical records and involved about 23,000 people at local community meetings. Furthermore, soil contamination investigations were conducted at 69 sites. Overall, more than 4,000 samples of ground water and soil, from numerous sites were analyzed. Although, the assessment was carried out in Ogoniland, the recommendations would serve as a guide for pollution management, elsewhere in the Niger Delta region. The following were highlighted in the report:

\subsection{Widespread Pollution in Ogoniland}

The findings from the unprecedented EA suggest that the environmental degradation arising from the widespread pollution is extensive. Therefore, a comprehensive environmental restoration effort is required for a full rehabilitation of Ogoniland that may require as many as 25 to 30 years completing. This necessitates an initial 1 billion dollars set aside for the first 5 years of a 30-year cleanup project in Ogoniland alone.

\subsection{Faulty Institutional Frameworks}

The major petroleum regulatory bodies - the Department of Petroleum Resources (DPR), and the National Oil Spill Detection and Response Agency (NOSDRA) have conflicting apprehension, 
and subsequently, implementation of the dictates of the Environmental Guidelines and standards for regulating the petroleum Industry in Nigeria (EGASPIN). EGASPIN was issued in 1991 by DPR to enforce compliance with existing environmental regulations by the petroleum industry operators, so as to safeguard the environment from degradation by their activities. It was prepared following the Petroleum Act of 1969 [40, 41].

The lack of consistency with established regulations contained in EGASPIN, as well as a lack of agreeable implementation, have led to various forms of mismanagement, and infractions of best practices, including premature shutting off of remediation process before contamination has had a chance to be eliminated, and soil or water quality restored. A revised publication of EGASPIN was published in 2002. Even though EGASPIN constitutes the sole operational groundwork for environmental governance of the Nigerian oil industry, it has been found deficient. Constitutional incoherence regarding the most vital requirement for oil spill and contaminated site management particularly, the criteria which trigger remediation or highlights its closure (called the 'intervention' and 'target' values respectively) [2]. These responsible government regulatory authorities were reported to be inadequate in terms of technical expertise, and other vital resources. For instance, NODSRA, even 5 years after its establishment lacked proactive capacity to productively and economically detect spills, and proffer lasting remediation processes. Further, in most oil spill site inspections, they are completely dependent on the oil companies for logistics backing.

\subsection{SPDC's poor EM practices and policy implementation}

Although, several MOCs operate in Ogoniland, SPDC operations have been determined to be the principal cause of the widespread pollution. UNEP reported that 10 out of the 15 investigated sites which SPDC records pointed out as having completed remediation, still had pollution exceeding the SPDC, as well as government regulatory remediation closure values. Moreover, the report also suggests that the contamination at eight of these sites had migrated to groundwater. UNEP's report evidenced SPDC's deficient remediation processes, described as unfit for Ogoniland, and therefore requiring scrutiny and reevaluation. Furthermore, completed remediated spill sites were inaccurately recorded. The report also highlighted the ineffectiveness of the remediation by natural attenuation (RENA), the only remedial method adopted by SPDC, therefore its inadequacy to either accomplish environmental clean-up nor regulatory conformance; as well as meeting requirements of SPDC's own established procedures.

\subsection{Nsisioken Ogale Community}

The most serious case of groundwater contamination is in Nisisioken Ogale, where an $8 \mathrm{~cm}$ layer of refined oil was observed floating on the groundwater that serves the community wells. Additionally, members of the community were drinking water from wells contaminated with benzene, a known cancer-causing chemical, at levels over 900 times above the World Health Organization (WHO) guidelines. The EAR emphatically categorized required action on this matter as "emergency measures". The medical registry and meticulous follow-up for people of this community, as well as provision of adequate safe drinking water, were also classified as "priority measures" [2]. Furthermore, UNEP specifically emphasized prioritizing required emergency action, ahead of all other remediation action, in responding to the Nsisioken-Ogale dilemma. Research suggests that in instances where water was provided, it was inadequate and sporadic, forcing people 
to drink the contaminated water, as they lacked other alternatives. A more recent report also suggests that initial sporadic water supply, has ceased altogether [1].

\subsection{Other Public Health Issues}

A very disturbing finding by [2] is that the Ogoni community is unprotected against petroleum pollutants, in both outdoor air and drinking water, sometimes at high concentrations. They are also exposed through skin contact from contaminated environmental media, including soil, sediments, and surface water. Also, seeing that the average life expectancy in Nigeria is below 50 years, it may be reasonably fair to assume that most members of the current Ogoniland have lived with protracted oil pollution throughout their lives.

At 10 communities where sampling was carried out, 28 wells were detected to have been contaminated with organic pollutants, seven of whose samples were at least 1,000 times higher than the Nigerian drinking water standard of $3 \mu \mathrm{g} / \mathrm{L}$. The sad truth is that despite community awareness of the dangers surrounding use of water from such polluted sources, they lack alternatives.

\subsection{Benzene}

The study findings also report benzene in all air samples at levels ranging from 0.155 to 48.2 $\mu \mathrm{g} / \mathrm{m}^{3}$. The report asserts that an estimated 10 per cent of benzene concentrations detected in Ogoniland were above the specification levels of global regulations such as WHO and the United States Environmental Protection Agency (USEPA). This concentration corresponds to a 1 in 10,000cancer risk. Benzene is classified as a known carcinogen based on occupational studies in adults who demonstrated increased incidence of several types of leukemia on exposure [42 - 44]. Furthermore, the WHO International Agency for Research on Cancer (IARC) in 1998, classified benzene as a known (Group 1) human carcinogen, based on sufficient evidence that it is cancer causing to humans [45]. Moreover, evidence suggests that it brings about DNA damage (genotoxicity) in experimental animals [42 - 44]. Benzene is one of 188 hazardous air pollutants (HAPs) listed under section 112(b) of the 1990 Clean Air Act Amendments and regulated from more than 170 industrial source categories [46].

\section{Discussion}

A crucial finding included in UNEP's report is the fact that SPDC failed in conforming to its own Standard Operating Procedures (SOP), as per Industry Best Practices (IBP), as well as those of the government. This failure is observed in the ramifications of EM, environmental health, as well as policy and regulations. Also, tons of research studies have consistently pointed to the inadequate implementation of existing environmental protection laws such as the Environmental Impact Assessment (EIA) Act, as the principal cause of the Niger Delta environmental degradation. Unless adequate action is taken by the responsible parties - the Nigerian government and MOC's including SPDC, the environmental and public health, as well as, policy and socioeconomic problems, which have consistently plagued the region may remain unabated. Based on the issues highlighted, in the preceding chapters, possible solutions are discussed in the ensuing paragraphs. 


\subsection{Environmental Management / Environmental Management System Model (EM/EMS) Model}

I developed this model based off EPA's "Learn about Environmental Management Systems."; “ISO 14001:2015-Environmental Management Systems - Requirements with guidance for use." and Barrow's "Environmental Management and Development." Other models sprung as offshoots of the EM/EMS model; however, I decided to use them for subsequent publication.

“...Environmental management transcends achieving sustainable development, one of its primary goals, but in addition, it promotes awareness, recognition and informed decision to mitigate hazards to communities, the environment, including plant and animal life, as well as recovery of damaged ecosystems. It also expedites human adaptability enhancement..." [47] (p. 13). Other definitions have been put forth by various scholars and international bodies, including [48], who suggests that, EM is the system that visualizes and in advance prepares for, and circumvents, or provides solutions to environmental and resource sustentation problems. Although these translations may indicate diverse approaches, they all have a single theme-environmental preservation, which many have deemed lacking in the agenda of the MOCs operating in the Niger Delta region.

Even though sustainability and sustainable development constitute major EM goals, an overarching goal of EM, is environmental public health security (Figure 2). Achieving sustainability and sustainable development fructifies the overarching goal of EM. At this point, it is important to not confuse sustainability and sustainable development. While the former refers to the continuous, uninterrupted ecosystem activity, or resource use, and signifying steady demands; the latter refers to improvement of human welfare and lifestyles and, in the predictable future, entails growing demands [47]. The Brundtland Commission defines it as, the development that satisfies the needs of the present generation without jeopardizing the ability of future generations to meet their own needs. Both are interrelated and are very important components of EM [47].

According to the US EPA, EMS refers to the structure that affords an organization the potential for attaining its environmental goals, by making adequate provisions for the continual "management affairs" including evaluation, review, and improvement of its environmental performance, in a planned and systematic way (Figures 2 and 3). EMS due to its proactive nature, facilitates an organization's capacity to address its regulatory requirements, in not only an organized style, but also in a cost-effective manner, enhancing reduction in non-compliance risk, and improvement of public health and safety. Another very important component of EMS is environmental impact assessment (EIA) (Figure 2). It is "the process of systematically recognizing and appraising of the probable effects of proposed prospective legislative actions, plans, programs, or projects, relative to the biological, chemical, cultural, physical, and socioeconomic elements of the environment [49]. On the other hand, environmental audit, simply put, refers to the organized evaluation of the interplay between a business operation and its surrounding environment. This encompasses all effluent discharges to air, land and water legal constraints; ecology, impacts on host community, as well as the public's perception of the business operation in the local area [50]. 

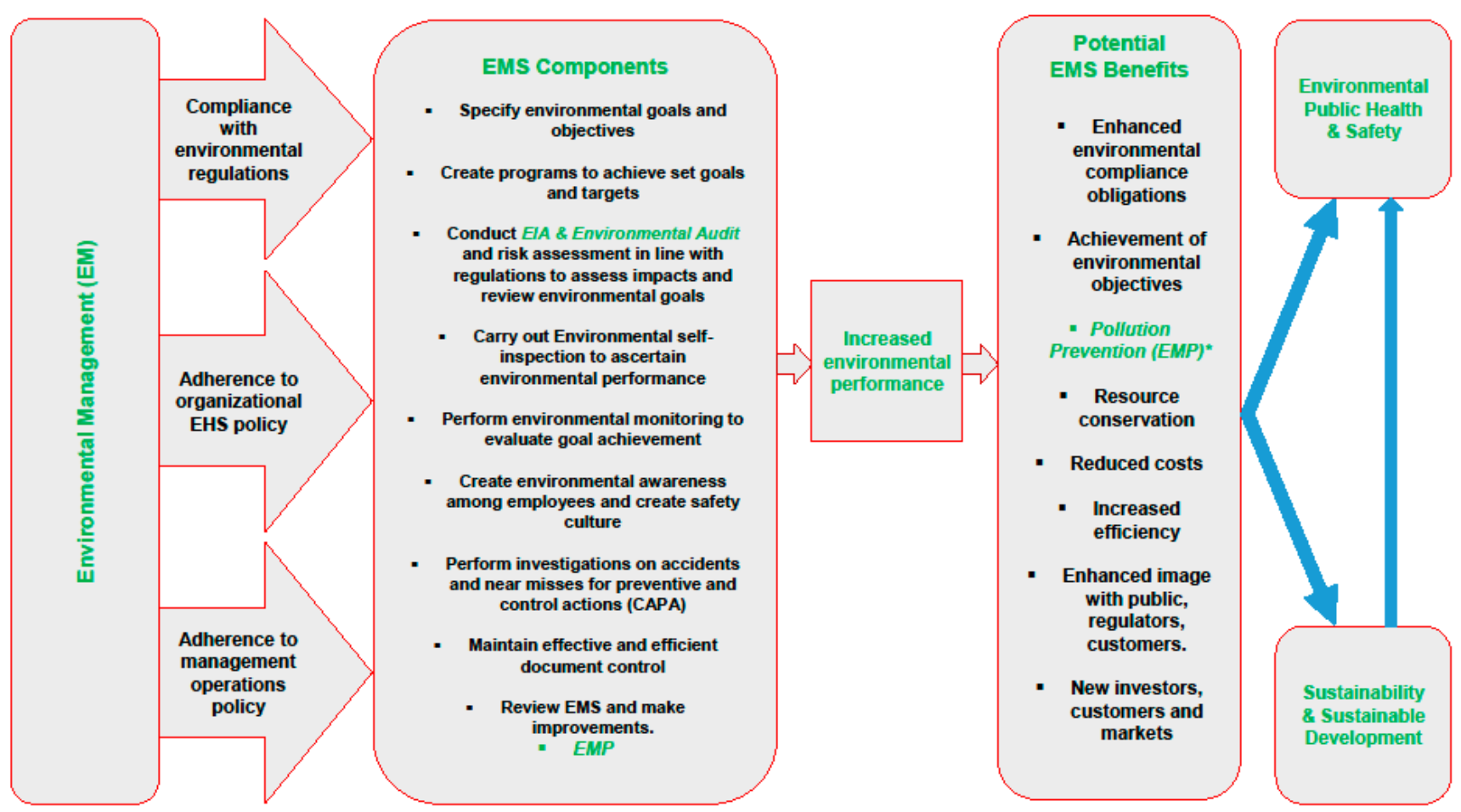

Figure 2. EM/EMS Model EM- Environmental Management; EMS-Environmental Management System; EIA Environmental Impact Assessment *EMP- Environmental Management Plan

\subsection{Environmental Management Plan (EMP)}

[51] describes EMP (Figure 3) as the plan, drawn up during the EIA process that spells out a description of the methods and procedures for checking and reducing impacts. It enhances the awareness and adoption of EM best practices by business and project owners. EMP should be fundamentally entrenched in considerations of resource prevention and pollution abatement, including, air pollution, liquid effluents, solid wastes, noise pollution, disaster planning, environmental responsibilities, house-keeping, human settlements, recovery - reuse of waste products, occupational safety and health prevention, maintenance and operation of environment control systems, vegetal cover, among others. [52].

The forgoing predicaments, are issues that EM seeks to effectively address. In fact, businesses with EM best practices in place may be considered as adopting the "costs of avoidance." 

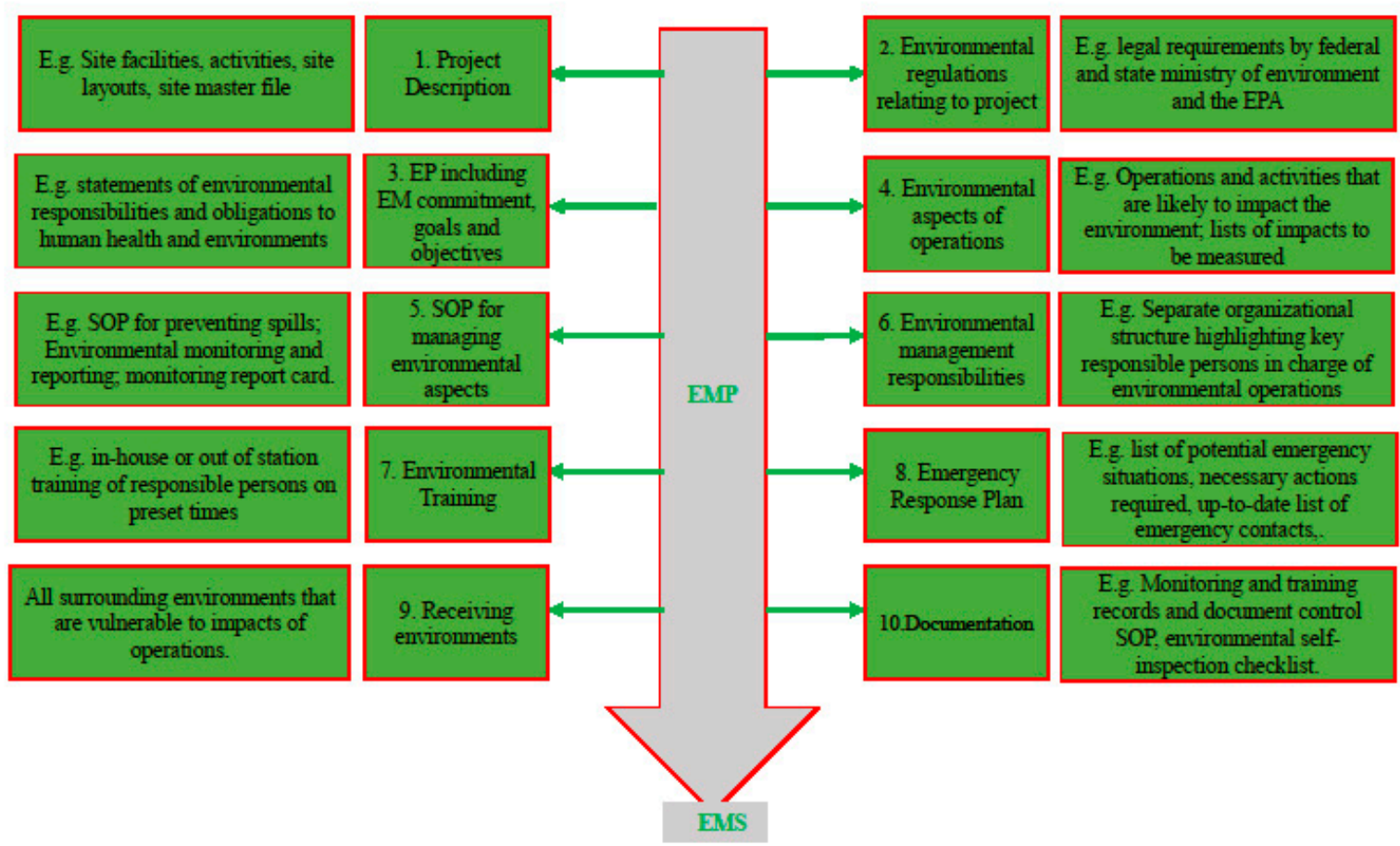

Figure 3. EMP components

\section{EP=Environmental Policy; SOP=Standard Operating Procedure; EMS=Environmental} Management Systems

\subsection{Pollution Prevention}

The extent to which EMS is adopted determines what the outcome for pollution prevention is. According to the US Pollution Prevention Act of 1990 [53], pollution prevention, also referred to as source reduction, describes the practice of reducing to the barest minimum, the amount of hazardous substances, or contaminants introduced into any waste stream, or otherwise discharged into multimedia (air, water and land), prior to recycling, treatment or disposal (Figure 3). It also refers to reduction of hazards to environment and public health, by operations involving the discharge of such contaminants or pollutants.

ISO 14001, the International Organization for Standardization on Environmental Management Systems, defines pollution prevention as the adoption of processes, practices, techniques, materials, products, services, substances or energy that avoid or minimize or control (separately or in combination) the creation, emission or discharge of any type of pollutants or wastes thus reducing adverse environmental impacts [54]. 
Pollution prevention can be achieved by process or procedure modification, equipment and technology redesign as well as reformulation of products. Improvements in maintenance, housekeeping, inventory control and training programs are all pollution prevention efforts. The benefits of pollution prevention cannot be over emphasized. Businesses enjoy substantial benefits from pollution prevention programs including costs savings from reduced raw material, pollution control, and liability costs, as well as environmental preservation, and risks reduction among workers, in terms health and safety [55]. In its own view, [56] emphasizes the relevance of Integrated Pollution Prevention and Control from the perspective of assuring environmental quality, by discouraging different approaches that may ultimately bring about shifting of pollution between the different environmental media but rather, adopt holistic measures, to safeguard the environmental as a whole. This makes up a very important aspect in the efforts to engender a more sustainable balance between human activities and socio-economic development, on the one hand, and resources and the capacity of the earth to adequately regenerate on the other [56]. Pollution control on the other hand refers to waste handling or management of wastes generated from industrial processes and operations [55,57]. This end-of-pipe approach has over the years paid off in terms of providing shortterm improvements for local pollution problems, however, emphasis have over time shifted to pollution prevention largely owing to risks of transferring pollution from one media to another [57, 58] involved in pollution control measures, ever increasing costs of abatement processes and operations, and its less effectiveness in addressing cumulative problems on regional (e.g., acid rain) or global (e.g., ozone depletion) levels [58].

\subsection{Conclusion}

There has been long-term oil production-related environment pollution in the Niger Delta. This pollution especially impacts the Ogoni people in terms of environmental public health problems. Despite efforts by the MOSOP and the UNEP, the Nigerian government and SPDC have not adopted UNEP's recommendations.

The UNEP report on restoration of the damaged environment is all-encompassing, and contains recommendations on all impacted aspects of the communities. Implementing the recommendations will go a long way in rehabilitating the devastated region. We recommend that the Nigerian Federal Government develop a clear-cut remediation plan towards achieving full execution of the report. This would serve as a means for coordinating efforts for the restoration in other oil-impacted communities in the Niger Delta region. The graphical abstract may also serve as a conceptual model that attempts to explicate the current Ogoni situation, and the anticipated outcomes of the implementation of UNEP's recommendations

Acknowledgements: I will like to thank Dr. Blair Stringam of the Department of Plant and Environmental Sciences, and Dr. Joseph Gladstone of the Department of Public Health Sciences, New Mexico State University, for kindly reviewing my draft manuscript.

Conflicts of Interests: I declare no conflict of interest. 


\section{Appendix:}

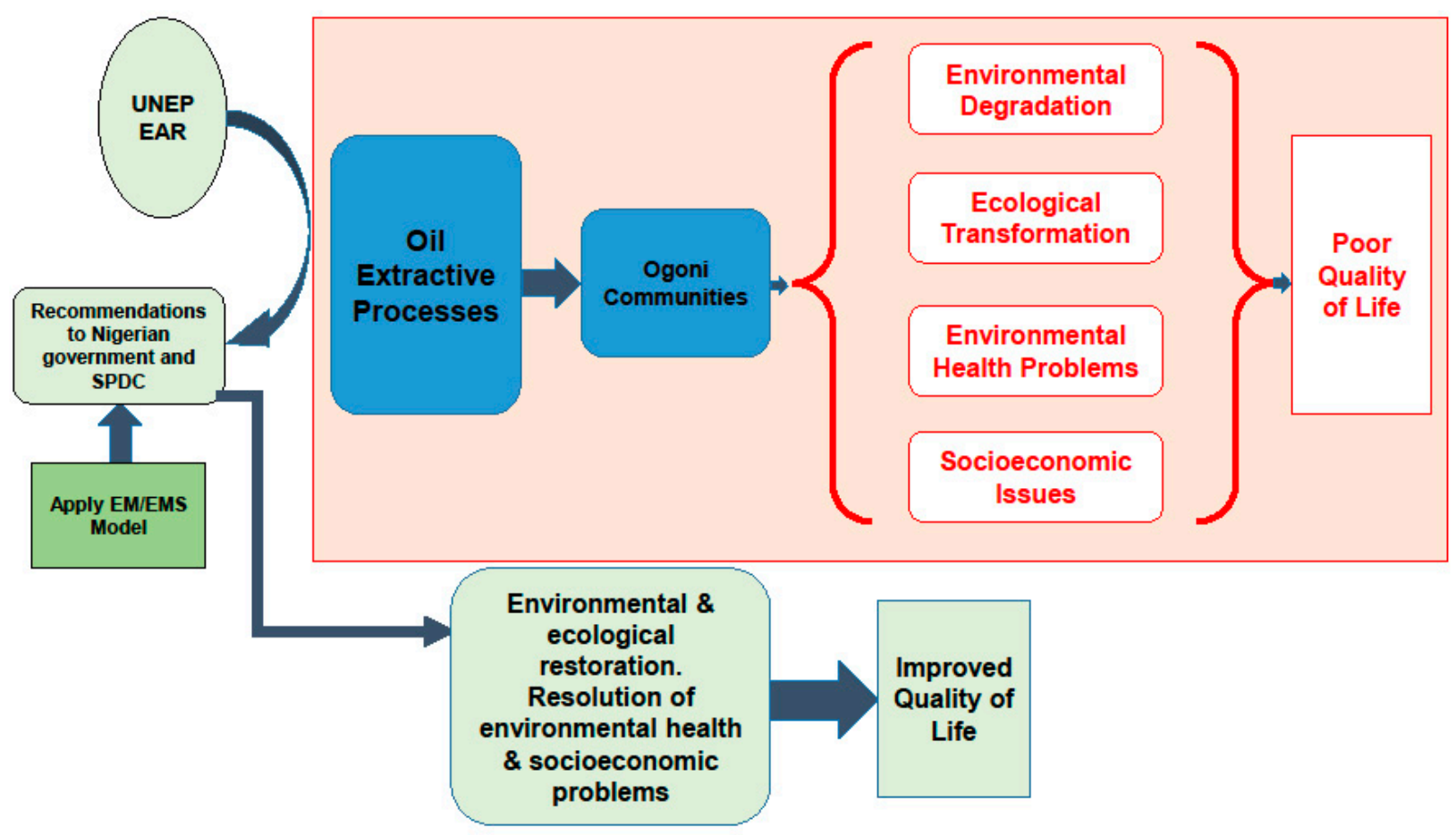

\section{A1. Abstract Graphic.}

\section{References}

1. Platform. Polluted Promises: How Shell Failed to Clean Up Ogoniland. Available online: http://platformlondon.org/wp-content/uploads/2014/05/Polluted_Promises_FINAL_low_res.pdf (accessed on 24 December 2016).

2. United Nations Environmental Program (UNEP). Environmental Assessment of Ogoniland. Available online: http://postconflict.unep.ch/publications/OEA/UNEP_OEA.pdf (accessed on 29 December 2016).

3. Agbonifo, J. Territorializing Niger Delta Conflicts: Place and Contentious Mobilization. Interface: a journal for and about social movements. 2011, 3, 240 - 265.

4. Tamuno, S.; Felix, J.M. Crude Oil Resource: A Blessing or Curse to Nigeria - The Case of the Niger Delta. Jorind. 2006, 4, 53-58. doi.org/10.4314/jorind.v4i2.42332.

5. African Vault. Top 20 Oil Producing Countries in Africa. Available: http://www.africanvault.com/oil-producing-countries-in-africa/ (accessed on 13 December 2016).

6. Pitkin, J. Oil, Oil, Everywhere: Environmental and Human Impacts of Oil Extraction in the Niger Delta. Senior Thesis, Pomona College, Claremont, CA, USA, 2013.

7. Balouga, J. The Niger Delta: Defusing the Time Bomb. International Association for Energy Economics. Available online: 
https://www.iaee.org/documents/newsletterarticles/109balouga.pdf. (accessed on 27 December 2016).

8. Barbier, E.B.; Acreman, M.C; Knowler, D. Economic Valuation of Wetlands, A Guide for Policy Makers and Planners; Ramsar Convention Bureau: Gland, Switzerland, 1997.

9. Wetlands International. Conserving and restoring wetlands in Nigeria's Niger River Delta. Available online: https://www.wetlands.org/casestudy/conserving-and-restoring-wetlands-innigerias-niger-river-delta/ (accessed on 28 December, 2016).

10. Ite, A.E.; Ibok, U.J. Gas Flaring and Venting Associated with Petroleum Exploration and Production in the Nigeria's Niger Delta. American Journal of Environmental Protection. 2013, 1, 7077. doi: 10.12691/env-1-4-1.

11. Okonkwo, C.N.P.; Kumar, L.; Taylor, S. The Niger Delta Wetland Ecosystem: What Threatens It and Why Should We Protect It? Afr. J. Environ. Sci. Technol. 2015, 9, 451- 463, doi: 10.5897/ajest2014.1841

12. Europe-Third World Centre (CETIM); Environmental Rights Action/Friends of the Earth Nigeria (ERA/FoEN). Cases of Environmental Human Rights Violations by Shell in Nigeria's Niger Delta. Available online: http://www.cetim.ch/wp-content/uploads/G1404473.pdf (accessed on 26 December 2016).

13. Barry, F.B. Environmental Injustices: Conflict and Health Hazards in The Niger Delta. Masters Thesis, American University, Washington, NW. USA, 2010.

14. Godson, A.R.; Sridhar, M.K.; Bamgboye, E.A. Environmental Risk Factors and Health Outcomes in Selected Communities of the Niger Delta Area, Nigeria. Perspect. Public Health. 2009,129, 183191. doi: $10.1177 / 1466424008094803$.

15. Agency for Toxic Substances and Disease Registry (ASTDR). Toxicological Profile for Benzene. Available online: https:/www.atsdr.cdc.gov/toxprofiles/tp3-p.pdf (accessed on 24 December 2016).

16. Ndubuisi, O.L.; Asia, I.O. Environmental Pollution in Oil Producing Areas of the Niger Delta Basin, Nigeria: Empirical Assessment of Trends and People's Perception. Environ. Res. J. 2007, 1, $18-26$.

17. Environmental Rights Action/Friends of the Earth (ERA/FoE). Gas Flaring in Nigeria: A Human Rights, Environmental and Economic Monstrosity. Available online: https://www.foe.co.uk/sites/default/files/downloads/gas_flaring_nigeria.pdf (accessed on 27 December 2016).

18. Emam, E.A. Environmental Pollution and Measurement of Gas Flaring. Int. j. innov. res. sci. eng. technol. 2016, 2, 252-262.

19. Agency for Toxic Substances and Diseases Registry (ASTDR). Nitrogen Oxides. Available: https://www.atsdr.cdc.gov/toxfaqs/tfacts175.pdf (accessed 22 December 2016).

20. Agency for Toxic Substances and Diseases Registry (ASTDR). Interaction Profile for Benzene, Toluene, Ethylbenzene and Xylene. Available: https:/www.atsdr.cdc.gov/interactionprofiles/ipbtex/ip05-c3.p. (accessed 18 December 2016). 
21. Osuji, L.C.; Nwoye, I. An Appraisal of the Impact of Petroleum Hydrocarbons On Soil Fertility: The Owaza Experience. Afr. J. Agric. Res. 2007, 2, 318-324.

22. Nwaoguikpe, R.N. The Effect of Crude Oil Spill On the Ascorbic Acid Content of Some Selected Vegetable Species: Spinach Oleraceae, Solanum Melongena and Talinum Triangulare in an Oil Polluted Soil. Pakistan J. Nutr. 2011,10, 274-281. Available online: http://docsdrive.com/pdfs/ansinet/pjn/2011/274-281.pdf (accessed on 29 December 2016).

23. Osam, M.U.; Wegwu, M.O.; Uwakwe, A.A. The Omoku Old Pipeline Oil Spill: Total Hydrocarbon Content of Affected Soils and The Impact On the Nutritive Value of Food Crops. Arch. Appl. Sci. Res. 2011, 3, 514-521.

24. Ordinioha, B.; Brisbe, S. The Human Health Implications of Crude Oil Spills in The Niger Delta, Nigeria: An Interpretation of Published Studies. Niger. Med. J. 2013, 54, 10-16. doi: 10.4103/03001652.108887.

25. Clinton, H.I.; Ujagwung, G.U.; Horsfall, M. Evaluation of Total Hydrocarbon Levels in Some Aquatic Media in an Oil Polluted Mangrove Wetland in The Niger Delta. Appl. Ecol. Environ. Res.2009, 7, 111-120.

26. Andrade, V.T.; Andrade, B.G.; Costa, B.R.S.; Pereira, O.A. Jr.; Dezotti, M. Toxicity Assessment of Oil Field Produced Water Treated by Evaporative Processes to Produce Water to Irrigation. Water Sci. Technol. 2010, 62, 693-700. doi. 10.2166/wst.2010.340.

27. Kharaka, Y.K.; Otton, J.K.; Environmental Impacts of Petroleum Production: Initial Results from The Osage-Skiatook Petroleum Environmental Research Sites, Osage County, Oklahoma. Water-Resources Investigations Report 03-4260. Available online: https://pubs.usgs.gov/wri/wri03-4260/ (accessed on 25 December 2016).

28. Telleza, G.T.; Nirmalakhandan, N.; Gardea-Torresdey, J.L. Performance Evaluation of an Activated Sludge System for Removing Petroleum Hydrocarbons from Oilfield Produced Water. Adv. Environ. Res. 2002, 6, 455 - 470. doi.org/10.1016/S1093-0191 (01)00073-9.

29. Agbebi, F.O. Impact of Fish Farming on Poverty Alleviation in Ekiti State. Int. J. Sci. Nat. 2011, 2 , 456-460. Available online: http://scienceandnature.org/IJSN_Vol2(3)S2011/IJSN-VOL2(3)-3.pdf (accessed on 27 December 2016).

30. Ejelonu, B.C.; Adeleke, B.B.; Ololade, I.O.; Adegbuyi, O. The Chemistry of Rainwater Samples Collected Within Utorogu-Oil Producing Community in Niger Delta, Nigeria II. Eur. J. Sci. Res. 2011, 58, 189-203.

31. Nduka, J.K.; Orisakwe, O.E. Water-Quality Issues in The Niger Delta of Nigeria: A Look at Heavy Metal Levels and Some Physicochemical Properties. Environ. Sci. Pollut. Res. 2010,18, 237-246. doi 10.1007/s11356-010-0366-3.

32. Efe, S.I. Spatial Variation in Acid and Some Heavy Metal Composition of Rainwater Harvesting in the Oil-Producing Region of Nigeria. Nat. Hazards. 2010, 55, 307-319. doi: 10.1007/s11069-0109529-2. Available online: http://link.springer.com/article/10.1007\%2Fs11069-010-9529-2 (accessed on 27 December, 2016).

33. Nwankwo, C.; Ogagarue, D. Effects of Gas Flaring On Surface and Ground Waters in Delta State Nigeria. J. Geol. Min. Res. 2011, 3,131-136. 
34. Boele, R.; Fabig, H.; Wheeler, D. Shell, Nigeria and The Ogoni. A Study in Unsustainable Development: The Story of Shell, Nigeria and The Ogoni People - Environment, Economy, Relationships: Conflict and Prospects for Resolution. Sust. Dev., 2001, 9, 74-86 doi: 10.1002/sd.161.

35. Ite, A.E.; Ibok, U.J.; Ite, M.U.; Petters, S.W. Petroleum Exploration and Production: Past and Present Environmental Issues in The Nigeria's Niger Delta. American Journal of Environmental Protection. 2013, 4, 78-90. doi: 10.12691/env-1-4-2.

36. Odisu, A.T. The Nigerian State, Oil Multinationals and The Environment: A Case Study of Shell Petroleum Development Company (SPDC). J. Public Adm. Policy Res. 2015, 7, 24-28. DOI: 10.5897/JPAPR2014.0303.

37. Allen, F. The Enemy Within: Oil in the Niger Delta. World Policy Institute. Available online: http://www.worldpolicy.org/ (accessed on 26 November 2016).

38. United Nations Development Program (UNDP). Niger Delta Human Development Report. Available online: http://hdr.undp.org/sites/default/files/nigeria_hdr_report.pdf (accessed on 27 December 2016).

39. Amnesty International. Nigeria: Petroleum, Pollution and Poverty in The Niger Delta. Available online: https://www.amnesty.de/files/Amnesty_Bericht_Niger_Delta_09.pdf (accessed on 26 December 2016).

40. Department of Petroleum Resources (DPR). Environmental Guidelines and Standards for Petroleum Industry in Nigeria (EGASPIN). Revised ed. DPR, Lagos, Nigeria, 2002.

41. Ofuani, O.I. Environmental Regulation of Offshore (E\&P) Waste Management in Nigeria: How Effective? Law, Environment and Development Journal. 2011, 7, 79-99. Available online: http://www.lead-journal.org/content/11079.pdf (accessed on 6 November 2016).

42. Agency for Toxic Substances and Disease Registry (ASTDR). Toxicological Profile for Benzene. Available online: https:/www.atsdr.cdc.gov/toxprofiles/tp3-p.pdf (accessed on 24 December 2016).

43. U.S. Environmental Protection Agency (USEPA). Carcinogenic Effects of Benzene: An Update. Available online: https://cfpub.epa.gov/ncea/risk/recordisplay.cfm?deid=2806 (accessed on 24 December 2016).

44. U.S. Environmental Protection Agency (USEPA). Toxicological Review of Benzene (Non-cancer Effects). Available online: https://cfpub.epa.gov/ncea/iris/iris_documents/documents/toxreviews/0276tr.pdf (accessed on 28 December 2016).

45. International Agency for Research on Cancer(IARC). IARC Monographs on the Evaluation of the Carcinogenic Risk of Chemicals to Humans: Some Industrial Chemicals and Dyestuffs. Volume 29; IARC: Lyon, France, 1982; pp. $94-148$.

46. U.S. Environmental Protection Agency (USEPA). Technology Transfer Network Air Toxics Assessment: Original List of Hazardous Air Pollutants. Available: http://www.epa.gov/ttn/atw/188polls.html (accessed on 24 December 2016). 
47. Barrow, C. J. Environmental Management and Development, 2nd ed.; Routledge: New York, NY, USA, 2004; p 13.

48. Thompson, D. Tools for Environmental Management: A Practical Introduction and Guide. New Society Publishers: Gabriola Island, BC, Canada, 2002.

49. Council on Environmental Quality (CEQ). The Twenty-fourth Annual Report of the Council on Environmental Quality (U.S.). Available online: https:/ceq.doe.gov/nepa/reports/1993/toc.htm. (accessed on 28 December 2016).

50. Confederation of British Industry (CBI) 1990. Narrowing the Gap: Environmental Auditing Guidelines for Businesses. CBI, London, UK, 1990.

51. Rizzolo, J. Environmental Management: Code of Practice for the Building and Construction Industry. Ballymun Regeneration Ltd. - Health \& Safety Management Unit. Available online: http://www.brl.ie/pdf/ENVIRONMENTAL\%20MANAGEMENT.pdf (accessed on 26 December 2016).

52. Ministry of Environment, Forest and Climate Change (India). Environmental Management Plan (EMP). Available: http://www.moef.gov.in/citizen/specinfo/emp.html (accessed on 24 December 2016).

53. U.S. Environmental Protection Agency (USEPA). Pollution Prevention Act of 1990. Available: https://www.epa.gov/p2/pollution-prevention-act-1990 (accessed on 25 December 2016).

54. International Organization for Standardization (ISO), ISO 14001:2015-Environmental Management Systems - Requirements with Guidance for Use.,3rd ed.; ISO, Geneva, Switzerland, 2015.

55. U.S. Environmental Protection Agency (USEPA).2016. Learn About Environmental Management Systems. Available: https://www.epa.gov/ems/learn-about-environmentalmanagement-systems (accessed on 28 December 2016).

56. European Commission. Council Directive 96/61/EC of 24 September 1996 Concerning Integrated Pollution Prevention and Control. Available online: http://socios.ainia.es/mambiente/Doc/directiva\%20ingles.pdf. (accessed on 27 December 2016).

57. Owa, F.D. Water Pollution: Sources, Effects, Control and Management. M.J S.S.2013,4, 65-68. doi:10.5901/mjss.2013.v4n8p65.

58. Spiegel, J.; Maystre, L.Y. (1998). Environmental Pollution Control. In Encyclopedia of Occupational Health and Safety. 4th ed.; Stellman, J.M.; Ed.; International Labor Office. Geneva, Switzerland,1998; Volume 4, Available online: http://www.ilocis.org/documents/chpt55e.htm (accessed on 17 March 2016).

(C) 2016 by the author; licensee Preprints, Basel, Switzerland. This article is an open access article distributed under the terms and conditions of the Creative Commons by Attribution (CC-BY) license (http://creativecommons.org/licenses/by/4.0/). 